\author{
Markus Eberharter \\ Uniwersytet Warszawski
}

\title{
SOCJOLOGICZNE SPOJRZENIE NA ROLE TŁUMACZY LITERATURY. NA PRZYKŁADZIE WANDY KRAGEN I RECEPCII LITERATUR NIEMIECKOJĘZYCZNYCH W POLSCE PO 1945 R.
}

\begin{abstract}
Zarys treści: W oparciu o teorię pola, kapitału i habitusu Pierre'a Bourdieu w niniejszym artykule mowa jest o roli tłumacza jako aktywnego agenta w komunikacji literackiej. Omawiając twórczość translatorską, publicystyczną oraz literacką krakowskiej tłumaczki Wandy Kragen, autor artykułu analizuje jej zaangażowanie na rzecz umożliwienia wolnej od uprzedzeń recepcji literatury zachodnioniemieckiej w Polsce w latach 50. XX wieku, a także działania Kragen zmierzające do podniesienia kapitału społecznego tłumaczy. Przedmiotem badań jest również habitus tłumaczki oraz zagadnienie, na ile znajduje on odbicie w jej przekładach. Jako przykłady pracy translatorskiej Kragen służą fragmenty tłumaczeń z literatury austriackiej (S. Zweig) oraz zachodnioniemieckiej (H. Böll).
\end{abstract}

Słowa kluczowe: tłumaczenie literackie; habitus; rola tłumacza

Cdy pytamy o rolę i kompetencje tłumaczy, truizmem będzie stwierdzenie, Uże nie ograniczają się one wyłącznie do przekładu samych tekstów. Tłumacze mogą w istotny sposób ukierunkować recepcję danej literatury w kulturze docelowej, zarówno przez różne formy zaangażowania - od wyboru autorów i tekstów do przekładu, poprzez redagowanie zbiorów i antologii oraz pisanie recenzji wydawniczych, aż po działalność krytyczną i publicystyczną - jak i przez wybór strategii przekładu poszczególnych tekstów.

Warto jednak nie ograniczać się do samego opisania wymienionych czynności, lecz spróbować zrozumieć także okoliczności i uwarunkowania, w których zostały podjęte. Czyli zapytać np., czym mógł być motywowany 
wybór konkretnego autora przez danego tłumacza, jakimi intencjami kierował się wybierający i co chciał przez to osiągnąć. Warto też zastanowić się, jakie możliwości działania ma tłumacz w obrębie tzw. obiegu lub pola literackiego, gdyż znajduje się on w innej pozycji niż np. wydawca, agent literacki lub krytyk. W końcu ważnym pytaniem jest, jakie konsekwencje dla obrazu danej literatury lub danego autora mają takie, a nie inne działania tłumacza, czyli do jakiego stopnia współdecyduje on lub współtworzy znaczenie i wartość danej literatury w kulturze docelowej.

Szukając odpowiedzi na to pytanie, warto sięgnąć po wprowadzone do socjologii przez Pierre’a Bourdieu pojęcia agenta, pola, kapitału i habitusu, do których w ostatnich latach coraz częściej odwołuje się także przekładoznawstwo $^{1}$. Bourdieu zakłada, że wszystkie podmioty działające w obrębie tego samego obszaru - zwane przez niego agentami - siłą rzeczy wchodzą ze sobą w relacje, tworząc swego rodzaju strukturę społeczną, którą określa on mianem pola. Pozycja agenta zależy od kapitału, jakim dysponuje; tu Bourdieu rozróżnia cztery rodzaje kapitału: ekonomiczny, społeczny, kulturowy i przede wszystkim symboliczny, który zapewnia uznanie w oczach innych. Zajmowana przez agenta pozycja w polu wyznacza poza tym obszar jego działania: nie wszyscy mogą dokonać tych samych czynności, nie jest także bez znaczenia, kto daną czynność wykonuje. Natomiast dla określenia sposobu, w jaki dany agent wykonuje swoje działania, Bourdieu stosuje termin habitus. Habitus agenta, czyli jego modus operandi decyduje o tym, jak postrzega on i ocenia rzeczywistość, w której się porusza, i w jaki sposób w niej działa. Habitus jest przyswajany zarówno przez doświadczenia indywidualno-biograficzne, począwszy od wczesnego dzieciństwa, jak i przez doświadczenia kolektywne osób poruszających się w danym polu i przyjmujących przy tym pewną rolę, np. tłumacza w obiegu lub polu literackim. $W$ taki sposób pole i habitus agenta wzajemnie wpływają na siebie: uwarunkowania pola wyznaczają możliwości działania agenta, jego działania z kolei mogą zmieniać wewnętrzną strukturę pola. Agenci mogą bowiem przez swoje działania akumulować kapitał i dzięki temu poprawiać własną pozycję w danym polu, i w pewnym sensie też pozycję innych agentów, znajdujących się w podobnej sytuacji. Na przykład publikacja uznanego i chwalonego tłumaczenia wiąże się nie tylko ze wzrostem kapitału ekonomicznego (wynagrodzenie),

${ }^{1}$ Por. Bourdieu 1974 i 1993, a w szczególności: 2001. Syntetyczne wprowadzenie do jego koncepcji można znaleźć u Matuchniak-Krasuskiej 2010 oraz Schwingla 2011. Jeśli chodzi o zastosowanie teorii Bourdieu w przekładoznawstwie, por. np. Inghilleri 2005, Skibińska 2007 i 2008 (s. 35-40), Wolf, Fukari 2007 oraz Bachleitner, Wolf 2010. 
społecznego (znajomość z autorem, wydawcą) i symbolicznego (prestiż) dla poszczególnego tłumacza, lecz w całości poprawia status przekładów. Można przyjąć, że tłumacze są częścią pola literackiego danego kraju, gdyż stanowi ono kontekst, w którym powstają ich przekłady. Elementem wspólnym są bowiem agenci rodzimej i przekładowej produkcji literackiej, jak np. wydawcy, krytycy literaccy lub instytucje promujące literaturę, z którymi tłumacze muszą współpracować.

Takie podejście metodologiczne pozwala usytuować dany przekład w szerszym kontekście, związanym z jego powstawaniem. Pozwala także spojrzeć na przekład jako na produkt współdziałania kilku agentów oraz na opisanie, kto i dlaczego mógł przyczynić się do jego ostatecznego kształtu oraz do znaczenia, które ostatecznie przypada mu w kulturze docelowej. Umożliwia także odniesienie produktów kulturowych, w tym przekładów literackich, do rzeczywistości pozaliterackiej - np. społecznej lub historycznej - kultury docelowej, do której te przekłady wchodzą. Według Bourdieu poszczególne pola są wprawdzie autonomiczne w swoim funkcjonowaniu, stanowią jednak część całej rzeczywistości społecznej, również dzięki agentom, którzy w nich działają, często nie tylko w jednym $\mathrm{z}$ nich. Można więc w związku z tym zapytać, w jakich warunkach dany przekład powstał w kulturze docelowej lub jakie ślady w niej pozostawił.

Ponieważ koncepcja Bourdieu skupia się przede wszystkim na agencie, to i przy jej zastosowaniu do badań przekładoznawczych na pierwszy plan wysuwa się osoba tłumacza, co z kolei wpisuje się w silny nurt we współczesnym przekładoznawstwie ${ }^{2}$. Tłumacza próbuje się opisać jako agenta pola literackiego lub ściślej - tłumaczeniowego, jego zaś możliwości i motywy działania - przez habitus; zainteresowanie budzi także jego usytuowanie społeczne i biograficzne. Kluczowym pytaniem jest natomiast, na ile wszystkie wnioski dotyczące osoby tłumacza można odnieść do jego praktyki translatorskiej, czyli do konkretnych rozwiązań tłumaczeniowych stosowanych przez niego w przekładach. Dopiero wtedy bowiem można byłoby uzyskać pełen jego obraz jako aktywnego agenta w procesie transferu kulturowego.

Powyższe rozważania chciałbym zilustrować na przykładzie osoby i twórczości przekładowej Wandy Kragen, jednej z najbardziej znanych tłumaczek literatury niemieckojęzycznej przed II wojną światową i po niej, która

2 Por. np. Heydel 2013 (w szczególności s. 49-61 oraz 79-84). Jest to jedna z najnowszych prac z tego zakresu, podsumowująca dotychczasową literaturę na ten temat i ukazująca, że w ostatnich latach przekładoznawstwo w coraz większym stopniu interesuje się obecnością tłumacza w przekładach. 
na różnorodne sposoby przyczyniła się do recepcji literatur niemieckojęzycznych w Polsce w tym okresie. Kragen urodziła się w 1893 r. w Krakowie i była tłumaczką m.in. Josepha Rotha, Anny Seghers, Heinricha Bölla i Roberta Musila. Zmarła w 1982 r. $^{3}$

Żeby wyczerpująco opisać status tłumacza, w tym także tłumaczki Wandy Kragen, w polskim polu tłumaczeniowym lub literackim lat 50., konieczna byłaby obszerna jego rekonstrukcja, uwzględniająca przede wszystkim najważniejszych działających w nim agentów, takich jak krytycy literaccy, wydawnictwa, urzędnicy kultury i cenzury itd. Nie wchodząc w tym miejscu w szczegóły, zauważyć należy, że prestiż tłumacza prawdopodobnie nie był w tym okresie zbyt wysoki, o czym może świadczyć następujący przykład. W przemówieniu pod tytułem „O znaczeniu i godności tłumacza”, z okazji otwarcia tzw. studium przekładowego, organizowanego przez polski PEN-Club w latach 1950-1953, jego prezes Jan Parandowski stwierdził: „Tłumacz nie cieszy się zbyt dobrą sławą" (Parandowski 1955: 11). Ambicją organizatorów, mówił Parandowski dalej, jest zatem dowartościowanie zawodu i czynności tłumacza, albowiem „Tłumacz zdobywa swoją najwyższą godność wtedy, gdy jest świadom swojej misji szlachetnego pośrednika w wymianie dóbr" (Parandowski 1955: 20). Na początku lipca 1958 r. Parandowski otworzył w Warszawie Pierwszy Międzynarodowy Zjazd Tłumaczy Literatury Pięknej, z okazji którego Wanda Kragen opublikowała razem z inną tłumaczką, Marią Traczewską, tekst Tłumacze wychodza z cienia. W tym tekście wyraźnie widać staranie autorek, aby działać na rzecz tłumaczy, przyczynić się do zwiększenia ich kapitału symbolicznego. Piszą, że mimo tego, że prawie $90 \%$ produkcji wydawniczej stanowią przekłady, tłumacze, dzięki którym jest to możliwe, są niewidoczni i że mało kto zdaje sobie sprawę z ich pracy, w tym także profesjonalni krytycy literaccy. Piszą poza tym, na czym dokładnie polegają zadania, a także zasługi tłumaczy dla transferu kulturowego:

Tłumacz jest interpretatorem i przekazicielem dzieła obcojęzycznego, jest pośrednikiem między autorem dzieła a jego odbiorcą w obcym kraju. Od pracy, przygotowania i rzetelności tłumacza zależy kształt słowny dzieła napisanego w innym języku, jego przyswojenie mniej lub bardziej adekwatne i sumienne naszemu czytelnikowi (Kragen, Traczewska 1958: 4).

Jak u Parandowskiego w powyżej zacytowanym zdaniu, i tu widać świadomość szczególnej misji tłumacza jako łącznika pomiędzy autorem a czytel-

${ }^{3}$ Dokładną i wyczerpującą biografię Kragen przedstawia Wojciechowska 2011. 
nikiem lub pomiędzy kulturami. To tłumacz decyduje, w jakiej formie i w jaki sposób dzieło trafi do kultury docelowej, nadając mu ostateczny kształt, i dlatego jest tak ważny.

Sama Wanda Kragen starała się wypełniać to zadanie pośrednictwa równolegle z pracą przekładową. Na przykład jako jedna z pierwszych pokusiła się o rewizję utartego obrazu literatury zachodnioniemieckiej jako wyłącznie rewizjonistycznej i neofaszystowskiej, który dominował w Polsce do $1956 \mathrm{r}$. W artykule Na zachodzie sa zmiany z 1957 r. dokonuje rozliczenia z okresem po 1945 r., krytykując błędny, czarno-biały sposób patrzenia na RFN, co jej zdaniem prowadziło do zbyt jednostronnego obrazu Niemiec Zachodnich w oczach Polaków. Szczególnie zaś dla Polaków, pisze Kragen, jako najbliższych sąsiadów Niemców ważny jest zróżnicowany obraz Niemiec Zachodnich: „My w Polsce musimy wiedzieć nie tylko o żądzy odwetu i tendencjach rewizjonistycznych [...], ale także o tendencjach przeciwstawnych, wzmagających się tam ustawicznie" (Kragen, Traczewska 1958: 4).

Tendencje te znajdują wyraz np. w najnowszej literaturze RFN-u; najpopularniejszym $w$ tych latach $w$ Polsce autorem zachodnioniemieckim był Heinrich Böll, którego właśnie w ten sposób czytano. Kragen w dość istotnej mierze przyczyniła się do jego popularyzacji w Polsce. Po latach w liście do łódzkiego germanisty Krzysztofa A. Kuczyńskiego przyznaje nawet, że to właśnie ona poleciła Bölla na początku lat 50. swojemu pierwszemu polskie-

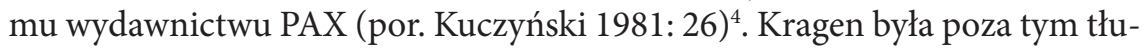
maczką pierwszej wydanej po polsku powieści Bölla I nie poskarżył się ani jednym słowem, która ukazała się w 1956 r. W tym samym roku opublikowała w „Tygodniku Powszechnym” także pierwszy krytyczny tekst o tym autorze (por. Kragen 1956), zanim jeszcze czołowi krytycy literaccy tego okresu, jak np. Marceli Ranicki, Jan Józef Lipski lub Aleksander Rogalski, zaczęli o nim pisać (por. Honsza 1997: 123-124). I w końcu Kragen towarzyszyła Böllowi podczas jego podróży do Polski w grudniu 1956 r., w tym do obozu koncentracyjnego Auschwitz-Birkenau, który wywarł na nim, jak relacjonuje tłumaczka, „wstrząsające wrażenie” (por. Kragen 1957: 9). W wymienionym tekście o Böllu znajduje się zdanie, które dobrze charakteryzuje sposób, w jaki Kragen przekłada go na polski: „Autor - pisze bowiem - nie zapuszcza zasłony na sprawy mroczne i straszliwe, za które winę ponoszą Niemcy, przeciwnie ukazuje wszystko w pełnym świetle" (Kragen 1956: 8). Analiza przekładu po-

${ }^{4}$ Innym autorem, o którym Kragen pisała jeszcze w latach 50., będąc jednocześnie tłumaczką jego dzieł, był Robert Musil. I w tym wypadku można by badać wpływ tłumaczki na kształt recepcji pisarza austriackiego w Polsce. 
wieści Gdzie byłeś, Adamie? pozwala zauważyć, że za pomocą stosowanych rozwiązań translatorskich, np. amplifikacji i drobnych przesunięć semantycznych, Kragen podkreśla właśnie sposób odczytania tekstu, który jest zbieżny $\mathrm{z}$ tezą, że Böll jest autorem zachodnioniemieckim, mówiącym wyraźnie o winie i zbrodniach Niemców.

Pokazuje to np. przywołane poniżej zdanie z jej przekładu powieści Bölla Gdzie byłeś, Adamie? Pochodzi ono z rozdziału siódmego, w którym zarysowany jest portret typowego niemieckiego nazisty, Filskeita. Jest on dokładny, posłuszny, nie lubi rozrywek, ma od dawna poglądy rasistowskie i już przed 1933 r. był związany z partią narodowosocjalistyczną. Za wszelką cenę chce uczestniczyć w wojnie, aż w 1943 r. staje się, należąc już do tzw. SS-Totenkopfverbände, komendantem nazistowskiego obozu koncentracyjnego. Jego poczucie obowiązku sprawia, że jest w stanie wykonać najbardziej okrutne rozkazy, potrafi także połączyć wysoką kulturę z okrutnym barbarzyństwem, np. każe bezsensownie zamordować wszystkich pozostałych jeszcze w obozie więźniów, a przy tym wszystkim jest uzdolnionym wielbicielem muzyki. Właśnie o tym jest mowa w następującym zdaniu, ukazującym Filskeita gdzieś na przełomie lat 20. i 30., kiedy był kierownikiem chóru i w jego zachowaniu ujawniły się już wszystkie negatywne cechy późniejszego zbrodniarza wojennego:

Die Sangesbrüder fürchteten ihn wegen seiner Genauigkeit, kein falscher Ton entging ihm, er brach in Raserei aus, wenn jemandem eine Schlampigkeit unterlief [...] (Böll 1958: 113).

W przekładzie Wandy Kragen to zdanie brzmi:

Członkowie chóru bali się go z powodu jego pedanterii. Nie uszedł mu żaden fałszywy ton, wpadał we wściekłość, gdy komuś zdarzyło się najlżejsze przeoczenie [...] (Böll 1989: 135).

Kragen uwypukla więc nieco negatywne cechy Filskeita, tłumacząc, że „członkowie chóru obawiali się go z powodu jego pedanterii” oraz że „wpadał [on] we wściekłość, gdy komuś zdarzyło się najlżejsze przeoczenie”. Filskeit bez wątpienia jest pedantem, natomiast nie ma tego explicite w oryginalnym tekście, jest to zatem interpretacja ze strony tłumaczki, tak samo, gdy tłumaczy ona niemieckie „Schlampigkeit”, czyli 'niedbałość jako „najlżejsze przeoczenie”. Wymienione przykłady nie powinny być oczywiście uznane za błędy w tłumaczeniu, raczej za świadome przesunięcie ze strony tłumaczki, 
chcącej przez to podkreślić wymowę oryginału. Takie rozwiązania translatorskie, które można zauważyć również w innych miejscach, sugerują pewien konkretny sposób odczytania tekstu - tu chodzi o negatywną charakterystykę niemieckiego nazisty - i do pewnego stopnia wychodzą naprzeciw oczekiwaniom czytelników. Ci może nie tyle szukali w tamtym okresie w literaturze zachodnioniemieckiej opisów bestialskich zbrodniarzy, ile chcieli, np. za pomocą subtelnych portretów psychologicznych, zrozumieć, jak Niemcy mogli być zdolni to tego, co robili podczas II wojny światowej. Opisany przykład pokazuje, jak aktywnie Kragen jako tłumaczka Bölla ukierunkowuje jego odbiór w Polsce, dbając o właściwą relację pomiędzy tekstem przekładanym a potencjalnymi odbiorcami w kulturze docelowej.

W staraniu Wandy Kragen o przysporzenie tłumaczom kapitału symbolicznego ${ }^{5}$ oraz $\mathrm{w}$ silnym akcentowaniu roli tłumacza jako pośrednika w dialogu międzykulturowym widać pewien nietypowy habitus tłumacza, a w tym wypadku - tłumaczki. Tę kategorię Bourdieu jako pierwszy zastosował do badań przekładoznawczych Daniel Simeoni, określając "habitus tłumacza” jako „czołobitny” i wyrażając pogląd, że tłumacze do tego stopnia przyswoili sobie swoją służebną rolę w polu kulturowym, że definiują siebie oraz swoją działalność właśnie przez nią:

The issue is that, for historical reasons that ought to be made clearer, translators seem to have been not only dependent, but willing to assume their cultural and socio-economic dependence - to the point that this secondariness has become part of the terms of reference for the activity as such. To become a translator [...] is to agree to becoming nearly fully subservient: to the client, to the public, to the author, to the text, to language itself or even, in certain situations of close contact, to the culture or subculture within which the task is required to make sense (Simeoni 1998: 11-12).

Również Parandowski zwraca uwagę w swoim już powyżej zacytowanym wystąpieniu, że „sami tłumacze zbyt często poddają się losowi i z rezygnacją przyjmują to mało zaszczytne stanowisko, jakie im opinia wyznacza" (Parandowski 1955: 12). Kontrowersyjna teza Simeoniego, która nie pozostała bez sprzeciwu (por. np. Sela-Sheffy 2005: 2-9), dotyczy habitusu kolektywnego tłumaczy, ja natomiast chciałbym się w tym miejscu skupić na habitusie indywidualnym Wandy Kragen, gdyż jest to związane z problemem bardzo

${ }^{5}$ Innym przykładem takich działań Wandy Kragen było ufundowanie przez nią stypendiów dla młodych tłumaczy, o czym pisze Bunsch (por. 1982: 13). Sama zaś otrzymała w $1976 \mathrm{r}$. nagrodę PEN-Clubu za przekłady z literatury obcej na polski (por. Kuczyński 1981: 26). 
trudnym i do tej pory raczej rzadko poruszanym w badaniach przekładoznawczych ${ }^{6}$. Habitus, jako indywidualny sposób działania danego agenta, można rekonstruować przede wszystkim za pomocą materiałów biograficznych, które w wypadku tłumaczy są z reguły nader skromne, w czym leży największy problem tego zagadnienia badawczego. W dodatku, o ile jeszcze decyzja, by zostać tłumaczem, lub wybór takich, a nie innych tekstów mogą odzwierciedlać się w biografii, o tyle dużo trudniejsze wydaje się odnoszenie pewnych faktów biograficznych do zastosowanych rozwiązań translatorskich lub szerzej - do konkretnej praktyki pracy przekładowej.

$\mathrm{Z}$ drugiej strony można znaleźć pewne zbieżności. Karol Bunsch podkreśla np. w nekrologu Wandy Kragen, że

działalność przekładowa była [dla niej - M.E.] [...] posłannictwem [...]. Założeniem jej było przyswojenie polskiej kulturze najznakomitszych dzieł literatury światowej, które umiała wychwytać z niezawodnym poczuciem smaku. [...] Często natomiast odrzucała propozycje przekładów dzieł, których poziom uważała za niski (Bunsch 1982: 4).

Tak właśnie rolę tłumacza jako aktywnego pośrednika międzykulturowego Kragen opisała w artykule Tłumacze wychodza z cienia. Podobnie jak dzisiejszym tłumaczom, zmuszonym do nieustannego zmagania się z twardymi warunkami ekonomicznymi na rynku książki, zapewne i tłumaczom z pokolenia Kragen niełatwo było nie przystać na ofertę przekładu ze strony wydawnictwa. W już zacytowanym liście Kragen do Kuczyńskiego sama tłumaczka wraca do tego faktu, dodając jeszcze jeden aspekt: „W istocie niemal wszystko, co przełożyłam, podsuwałam wydawcom, odrzucając nieraz ich propozycje” (za: Kuczyński 1981: 26). Świadczy to moim zdaniem niewątpliwie o silnym przekonaniu o wysokiej randze swojego zawodu, gdyż $\mathrm{w}$ zasadzie to ona sama dokonywała wyboru i decydowała, co tłumaczy, a czego nie. Jak odpowiedzialna w przekonaniu Kragen jest rola i praca tłumacza podkreśla także fakt, że jest to - jeżeli należycie wykonywana - praca bardzo czasochłonna i żmudna. Bunsch wspomina, że Kragen przy każdym wznowieniu swoich przekładów starannie je kontrolowała (por. Bunsch 1982: 4). Rzeczywiście, porównując wydania Marsza Radetzky'ego Josepha Rotha

${ }^{6}$ Dużo nowych wniosków na ten temat można się spodziewać po niedawno wydanej obszernej pracy Giselly Vorderobermeier pt. Translatorische Praktiken aus soziologischer Sicht: Kontextabhängigkeit des übersetzerischen Habitus? (Opladen 2013), do której podczas pisania niniejszego artykułu niestety nie miałem jeszcze dostępu. 
z 1934 r. i z 1958 r. lub Gdzie byłeś Adamie Heinricha Bölla z wcześniej opublikowanymi fragmentami tej powieści, widać wyraźnie ślady starannego opracowywania tekstu.

Poza tekstami dziennikarskimi, jak zacytowany powyżej nekrolog, także teksty literackie, więc fikcyjne, mogą posłużyć za źródła wiedzy o danej osobie. W 1932 r. pod pseudonimem Joanna Rudzka Wanda Kragen opublikowała Pamiętnik Marji, fikcyjny pamiętnik tytułowej bohaterki, który przed jej samobójstwem otrzymuje jej przyjaciółka Joanna, zawierający jednak wyraźne wątki autobiograficzne (por. Wojciechowska 2011: 200). Dlatego i w tym wypadku można podjąć próbę odniesienia tego tekstu nie tylko do osoby Wandy Kragen, lecz w dalszym kroku, także do jej pracy przekładowej. W jednym miejscu tego pamiętnika jest np. mowa o wybuchu I wojny światowej, który Maria przeżywa w Krakowie, w mieście, w którym i Kragen spędziła większość swojego życia. Czytamy:

A więc to prawda? Więc wojna, wojna, o której dotąd słyszeliśmy wyłącznie z historji, stała się faktem, stała się teraźniejszością? [...] Masowy obłęd: inaczej wojna jest nie do pojęcia. [...] Z możliwością wojny dziś, w Europie, liczono się conajwyżej teoretycznie. W jej przyjście nie wierzył nikt rozsądny. A jednak przyszła i rozgorzała nad starą, kulturalną Europą. Jak to pojąć? [...] Ale ta wojna XX wieku, do której doprowadziła chyba samobójcza "cywilizacja» przypomina w swym masowym, obłąkanym mordzie, gdzie żołnierz nie widzi żołnierza, tępienie szczurów w kanałach! A najokropniejsze w tem wszystkim, - to ten zupełny brak protestu z czyjejkolwiek strony, ten upadek tak głęboki, tak całkowity ducha ludzkości u wszystkich bez wyjątku narodów (Rudzka 1932: 50-51).

W zaskakująco podobny sposób mówi o tym zdarzeniu kilka lat później Stefan Zweig w swojej autobiografii Świat wczorajszy. Również u niego ta wojna, która była nie do pomyślenia, jest nie tylko końcem pewnej epoki w historii Europy i wyraźną regresją w dziejach ludzkości, lecz także niezrozumiałą masową psychozą:

Da, am 28. Juni 1914, fiel jener Schuß in Sarajewo, der die Welt der Sicherheit und der schöpferischen Vernunft, in der wir erzogen, erwachsen und beheimatet waren, in einer einzigen Sekunde wie ein hohles tönernes Gefäß in tausend Stücke schlug. [...] Und dann, was wußten 1914, nach fast einem halben Jahrhundert des Friedens, die großen Massen vom Kriege? Sie kannten ihn nicht, sie hatten kaum je an ihn gedacht. Er war eine Legende, und gerade die Ferne hatte ihn heroisch und romantisch gemacht. [...] 
Darum gingen, darum jubelten damals die Opfer trunken der Schlachtbank entgegen, mit Blumen bekränzt und mit Eichenlauf auf den Helmen, und die Straßen dröhnten und leuchteten wie bei einem Fest (Zweig 1992: 247, 261 i 263).

Zweig pisze swoją autobiografię w 1941 r. już na emigracji w Brazylii, dokąd musiał uciec przed nazistami, zostawiając i tracąc wszystko. W niektórych miejscach dostrzega uderzające analogie pomiędzy I a II wojną światową, co także przypomina słowa z Pamiętnika Marji:

[...] Europa ist mir verloren, seit es sich zum zweitenmal selbstmörderisch zerfleischt im Bruderkrieg. Wider meinen Willen bin ich Zeuge geworden der furchtbarsten Niederlage der Vernunft und des wildesten Triumphes der Brutalität innerhalb der Chronik der Zeiten; nie - ich verzeichne dies keineswegs mit Stolz, sondern mit Beschämung - hat eine Generation einen solchen moralischen Rückfall aus solcher geistigen Höhe erlitten wie die unsere. [...]

Uns war es vorbehalten, wieder seit Jahrhunderten Kriege ohne Kriegserklärungen, Konzentrationslager, Folterungen, Massenberaubungen und Bombenangriffe auf wehrlose Städte zu sehen, Bestialitäten all dies, welche die letzten fünfzig Generationen nicht mehr gekannt haben und künftige hoffentlich nicht mehr erdulden werden (Zweig 1992: 8 i 11).

Dzięki zbieżności w opisie i ocenie wojen światowych i ich skutków dla cywilizacji europejskiej można moim zdaniem założyć pewną empatię ze strony Kragen wobec tekstu Zweiga ${ }^{7}$. Świat wczorajszy ukazał się po polsku w 1958 r. w przekładzie Marii Wisłowskiej, Wanda Kragen natomiast już rok wcześniej przetłumaczyła przedmowę i przy porównaniu tych dwóch przekładów widać, w jaki sposób wspomniana empatia znajduje swoje odzwierciedlenie w sposobie, w jaki Kragen przekładała tekst Zweiga. Można bowiem zauważyć u niej wyraźnie liczne amplifikacje semantyczne lub emocjonalne, które potęgują wymowę tekstu. Z kolei w innych miejscach Kragen zachowuje jego patos, tam, gdzie Wisłowska go redukuje. Pokazuje to m.in. poniższy przykład. Najpierw tekst oryginału:

${ }^{7}$ Dodatkowym tekstem, który można by uwzględnić w tej analizie, jest pamiętnik W. Kragen z pierwszych tygodni okupacji niemieckiej w Warszawie w 1939 r., gdzie m.in. znajduje się zdanie: „Żal mi ludzi takich, jak Tomasz Mann. Jak on się musi wstydzić, że jest Niemcem” (Kragen 1965: 191), które właśnie przez fakt, że wyszło spod pióra tłumaczki-pośredniczki, niewątpliwie zyskuje na znaczeniu. 
Oder daß ich „bei uns” sage und erschrocken mich erinnern muß, daß ich für die Menschen meiner Heimat längst ebensowenig dazugehöre wie für die Engländer oder für die Amerikaner, dort nicht mehr organisch verbunden und hier wiederum niemals ganz eingegliedert; die Welt, in der ich aufgewachsen bin, und die von heute und die zwischen beiden sondern sich immer mehr für mein Gefühl zu völlig verschiedenen Welten (Zweig 1992: 9).

Przekład Marii Wisłowskiej brzmi:

Albo gdy mówię „u nas”, uświadamiam sobie, przerażony, że od dawna jestem dla moich rodaków kimś tak samo obcym, jak dla Anglików i Amerykanów. Z tamtymi nie jestem już organicznie związany, do tych nie przystałem jeszcze całkowicie. Coraz wyraźniej czuję, że świat mojej młodości, świat dzisiejszy i świat pomiędzy nimi dwoma - to trzy odrębne światy (Zweig 1958: 7).

I przekład Wandy Kragen:

Albo że mówię: „u nas” i przerażony przypominam sobie, że do ludzi mojej ojczyzny od dawna już nie przynależę, tak samo jak do Anglików lub Amerykanów, że tam nie jestem już z niczym organicznie związany, tutaj zaś nigdy nie wkorzeniłem się bez reszty. Świat, w którym wyrosłem, i świat dzisiejszy, i ten trzeci między tamtymi dwoma, w moim odczuciu stają się w coraz wyższej mierze zupełnie odrębnymi światami (Zweig 1957: 5).

W zakresie składni można zauważyć pewną redukcję ze strony Wisłowskiej, która dzieli wypowiedź Zweiga na dwa zdania, przez co staje się ona bardziej rzeczowa i mniej emocjonalna. Podobny efekt daje także wyłączenie słowa "przerażony” z toku płynnej wypowiedzi, co powoduje, że przestaje ono być jej integralnym elementem, stając się swego rodzaju dodatkiem. Bardziej rzeczowo brzmi tu także ostatni fragment cytatu, w którym trzy odrębne światy zostają po prostu wyliczone. Kragen natomiast jest dużo bliżej oryginału, kiedy np. właśnie w tym ostatnim fragmencie nie rezygnuje, jak Wisłowska, ze słowa „zupełnie”, co wyraża rozbicie tych światów, oraz z czasownika „stają się", co z kolei podkreśla procesualność utraty tego świata, do którego podmiot tekstu Zweiga pierwotnie przynależał. Jest to świat, jak Kragen tłumaczy, „w którym wyrosłem”, rozwiązanie Wisłowskiej: „świat młodości" brzmi tu nieco zbyt pozytywnie. To, że podmiot nie znajduje się już w znanym, bliskim sobie otoczeniu, Zweig wyraża w pierwszej części zdania, m.in. przez trudne do przetłumaczenia na polski słowo „Heimat”. Wisłowska 
z niego rezygnuje, pisząc, że podmiot jest obcy dla swoich rodaków. Kragen natomiast używa słów „ojczyzna”, co ma niewątpliwie mocną wymowę, a także „przynależę”, co podkreśla poczucie podmiotu, że został z tego kręgu wykluczony. Przez słowo „jeszcze” zaraz potem Wisłowska wprowadza pewną nadzieję, że pomiot może kiedyś przynależeć np. do Anglików. I tu Kragen jest bliżej oryginału i jego pesymistycznej wymowy, tłumacząc: „tutaj zaś nigdy nie wkorzeniłem".

Bliskość Kragen wobec tekstu Zweiga widoczna jest zatem w sposobie jego przekładu, zwłaszcza w wypadku tych miejsc, gdzie jest mowa o ciężkich doświadczeniach związanych z utratą świata, z którego się pochodzi, spowodowaną zniszczeniem „starej Europy” przez dwie wojny światowe. O ile więc Kragen w Pamiętniku Marji przetwarza własne doświadczenie biograficzne, to może ono tak samo być tłem, na którym czyta i przekłada tekst Zweiga. Wówczas można by uznać tę powieść za wyraz osobowości, a w pewnym sensie także habitusu Wandy Kragen jako tłumaczki, gdyż widać, jak odbiera ona i rozumie otaczającą jej rzeczywistość oraz jak na nią reaguje.

Na pewno osobowość tłumacza w pewien sposób wpływa na jego pracę, badania tych zależności nie mogą jednak wyjaśniać stosowania konkretnych rozwiązań translatorskich na zasadzie przyczyna-skutek. Także dla Bourdieu habitus nie jest mechanizmem, który determinuje agenta w jego działaniach, lecz pewnym systemem możliwych dyspozycji. Włączenie biografii tłumacza do badań nad jego przekładami daje natomiast niewątpliwie pełniejszy obraz samego tłumacza jako aktywnego agenta w transferze kulturowym.

\section{Literatura}

Bachleitner, N., Wolf, M. (red.), 2010, Streifzüge im translatorischen Feld. Zur Soziologie der literarischen Übersetzung im deutschsprachigen Raum, Wien-Berlin.

Böll, H., 1958, Wo warst Du, Adam?, Opladen.

Böll, H., 1989, Gdzie byłeś, Adamie?, tłum. W. Kragen, Warszawa.

Bourdieu, P., 1974, „Künstlerische Konzeption und intellektuelles Kräftefeld”,

[w:] tenże, Zur Soziologie der symbolischen Formen, Frankfurt (Main), s. $75-124$.

Bourdieu, P., 1993, „Über einige Eigenschaften von Feldern”, [w:] tenże, Soziologische Fragen, Frankfurt (Main), s. 107-114.

Bourdieu, P., 2001, Reguly sztuki. Geneza i Struktura pola literackiego, tłum. A, Zawadzki, Kraków. 
Bunsch, K., 1982, „Pamięć o Wandzie Kragen”, [w:] Życie Literackie, nr 7(1566), s. 4 i 13.

Heydel, M., 2013, Gorliwość tłumacza. Przekład poetycki w twórczości Czesława Miłosza, Kraków.

Honsza, N., 1997, Heinrich Böll niepokorny humanista, Wrocław.

Inghilleri, M. (red.), 2005, „Bourdieu and the Sociology of Translation and Interpreting. Special Issue", [w:] The Translator, No 11(2).

Kragen, W., 1956, „Heinrich Böll”, [w:] Tygodnik Powszechny, nr 15(553), s. 8. Kragen, W., 1957, „Na zachodzie są zmiany”, [w:] Życie Literackie, nr 10(268), s. 9.

Kragen, W., Traczewska, M., 1958, „Tłumacze wychodzą z cienia”, [w:] Życie Literackie, nr 31(341), s. 4.

Kragen, W., 1965, „Warszawa”, [w:] Polski wrzesień. Antologia pamięci 1939-1945, W. Żukrowski (red.), Warszawa, s. 183-193.

Kuczyński, K. A., 1981, Literatura Republiki Federalnej Niemiec w Polsce, Łódź.

Matuchniak-Krasuska, A., 2010, Zarys socjologii sztuki Pierre’a Bourdieu, Warszawa.

Parandowski, J., 1955, „O znaczeniu i godności tłumacza”, [w:] O sztuce tłumaczenia, M. Rusinek (red.), Wrocław, s. 11-22.

Rudzka, J., 1932, Pamiętnik Marji, Warszawa.

Schwingel, M., 2011, Pierre Bourdieu zur Einführung, Hamburg.

Sela-Sheffy, R., 2005, „How to be a (recognized) translator. Rethinking habitus, norms, and the field of translation", [w:] Target, No 17:1, s. 1-26.

Simeoni, D., 1998, „The Pivotal Status of the Translator's Habitus”, [w:] Target, No 10:1, s. 1-39.

Skibińska, E., 2007, „Stellung der Übersetzung im polnischen Literaturfeld nach 1989, [w:] Ikonen und Impressionen, T. Małyszek, J. Rzeszotnik (red.), Wrocław-Dresden.

Skibińska, E., 2008, Kuchnia tłumacza. Studia o polsko-francuskich relacjach przekładowych, Kraków.

Wojciechowska, M., 2011, „Wanda Kragen - tłumaczka, pisarka, podróżniczka", [w:] Krakowski szlak kobiet. Przewodniczka po Krakowie emancypantek, t. 3, E. Furgał (red.), Kraków, s. 193-210.

Wolf, M., Fukari A. (red.), 2007, Constructing a Sociology of Translation, Amsterdam-Philadelphia.

Zweig, S., 1957, „Świat dnia wczorajszego”, tłum. W. Kragen, [w:] Tygodnik Powszechny, nr 35(450), s. 5.

Zweig, S., 1958, Swiat wczorajszy, tłum. M. Wisłowska, Warszawa. 
Zweig, S., 1992, Die Welt von Gestern. Erinnerungen eines Europäers, Frankfurt (Main).

\section{A sociological view of the role of literary translators - Wanda Kragen and the reception of the literatures of the German-speaking countries in Poland after $1945 r$.}

Summary

The article describes the role of the translator as an active agent in literary communication on the basis of Pierre Bourdieu's theory of field, capital and habitus. This is exemplified by translations as well as critical and literary works of the well-known Polish translator, Wanda Kragen, that were written in the 1950s. First, the author shows how Kragen tried in her journalist work to elevate the symbolic social capital of translators in Poland in that period and directed her activities so that the reception of the West-German literature in Poland could be unbiased. This is related to her understanding of the translator's tasks, with the translator being an active creator of intercultural relations. This aspect is illustrated on the example of Kragen's translation of Heinrich Böll's novel Wo warst du, Adam?, where slight semantic shifts applied by the translator suggest a certain way to read and perceive the novel. In the second part of the article, the translator's habitus and the question how it affects translations themselves are subject to analysis. The example that is used to discuss this issue is the novel entitled Pamiętnik Marji, written by Wanda Kragen in 1932, and her translation of Stefan Zweig's autobiography Die Welt von Gestern from 1957. Although it is not possible to explain some solutions that Kragen used in accordance with the "cause and effect" principle, one can notice that a personal attitude, e. g. towards certain historical events, created by Kragen in her novel, is at the same time the contextual background, in view of which she translated the autobiography of Zweig.

Keywords: literary translation, habitus, the translator's role

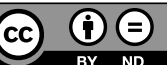

